\title{
Institutional Performance in Albania Regarding Social Protection Policies
}

\author{
Anisa Proda \\ anisaproda@gmail.com \\ European University of Tirana
}

\begin{abstract}
Albania is often considered "the most difficult case" of regime change compared to other ex-communist countries of Central and Eastern Europe. The long way, often too hard and chaotic, towards democracy and market economy put the country into a disadvantageous situation in comparison with other ex-communist countries because of the limited progress in these directions. Structural changes in Albania before and after the 90's are extraordinary. Now Albania is in a European integration phase, which means there's a series of standards to accomplish and political-economic challenges to be faced. In the first part, this paper will give a chronological view of social protection policies in Albanian going through the major historical phases such as communist regime and pluralist regime period. In the second part, our main focus will be the change in political regime and its consequences which dictated the need for new social protection policies. The inclusion policy or the policy of social protection in Albania is a component of a greater general frame named National Strategy for Development and Integration (SKZHI) 2007-2013, which brings in a single document the perspectives of social and economic stable development, in the framework of the integration in the UE and realization of the Millennial Objectives (SKZHI, 2008). The main social groups and social fields treaded by the policy documents such as National Strategy on Development and Integration, National Strategy on Social Protection, National Strategy on Social Inclusion will be explained. In the third part, social security and health care policies and institutions will be treated concluding with some findings from the empirical research.
\end{abstract}

Keywords: Institutional performance, Albania, social, protection, policies

\section{Introduction}

Social protection policies began quite late in Albania compared with other countries of the region, dating since the creation of the Albanian state in 1912. During the communist period, there was no "official" social policy, because the "special protection was a natural part" of the production processes, of the generation and distribution of the income, which was centrally directed by the state. Nevertheless, social protection was realized on some levels and was oriented towards different groups of the society. Despite the relatively complete legal framework, it's implementation remains one of the main problems in our country.

After the rise of the communist regime, the communist party took full control over the state and society and implemented a russian type of governance, just like other ex-Yugoslavia countries did (Institute of Social Work and Social Policy, Skopje). According to researchers, countries like Albania did not need an "official" social policy, because the "special protection was a natural part" of the production processes, of the generation and distribution of the income that was centrally directed by the state (Pfaller, 2001). Participation in the production processes gave people the right to share the consumption of the products either they were economically active or not, due to age, illness, disability or child birth (Pfaller, 2001). The state decided what should have been produced and how consumption right should have been distributed, determining the income level and the prices (Pfaller, 2001). There was a free and universal access to education for everybody, depending on their age, ability and of course loyalty to the regime. Free access to medical services and other types of services was offered as 
well, despite the purchasing ability of the individual. The state ensured even the accommodation (Pfaller, 2001). Access to a lot of social services, such as kindergarten for children and free time activities were organized by the institution where people used to work.

These institutions offered generous benefits because they did not depend on the balance between costs and respective product selling income, but on the funds that the government assigned for the employees' wages and welfare (Pfaller, 2001). Employment by command was also part of the social "duties", which assigned people to different institutions, factories, cooperatives, despite the production needs. This way, the system simply did not let the employment be materialized by the system and everyone who wanted to work and was able to do it, could keep the placement (Pfaller, 2001).

The transformation of the political systems brought radical changes to this situation. There is no warranty in the market economy that the income from the job will cover the needs, there is no job guaranteed or if it is, the salary might be really low. Furthermore, necessary goods and services for a normal life, such as accommodation and health care, or crucial services for people's future such as education, are not available for who cannot afford their costs (Pfaller, 2001). So, market economy brings the risk of social exclusion. However, there is some solidarity because the society is interested to ensure the welfare of as many of its citizens as possible. That's how the need for social protection policies and strategies that extenuate the negative effects of market economy arises. While in centralized economies the decision to distribute the resources was a political will, in market economies this distribution is based on the balance between buyers and sellers. In this case, most of the resources that support the reduction of social exclusion, belong to the private sector, although the state can generate itself some income through the activities of the productive structures that it owns.

This way, the political will, which in this case represents the will of the majority of the society since we're talking about democratic systems, can "force" citizens to pay part of their income, through taxes and contributions, to funds or particular structures, like social insurances system or health care (Pfaller, 2001). This is the way how democratic societies express their solidarity to vulnerable groups. Still, the implementation of the law remains a major problem (Bertelsmann Stiftung, 2014). In this context, it would be of interest to study the social protection scheme in Albania.

\section{Methods}

This study is based on twenty half-structured interviews with directors of regional Offices of State Social Service in 12 districts off Albania, two national officer from the Directorate of Social Protection Policies at the Ministry of Social Welfare and Youth, two national officers of Social Security Institute, two national officers of Health care Institute, a national officer of United Nations Development Program in Albania, the Director of Social Services in the Municipality of Albania. The interviews were carried out during February-march 2016 individualy or in pairs. The view expressed in this paper is completed also with the work experience of the author in the field of social policies.

\section{Social protection system in Albania}

The regulatory system of social protection in Albania is relatively complete, accepting some changes, amendments, continuous and occasional improvement, motivated by social, economic, political and demographic changes in the country, also in accordance with international recommendations and experience.

Albania is often considered "the most difficult case" of regime change compared to other ex-communist countries of Central and Eastern Europe. The long way, often too hard and chaotic, towards democracy and market economy put the country into a disadvantageous situation in comparison with other ex-communist countries because of the limited progress in these directions (Broadband Commission for Digital Development, 2012).

From the 90's and on, looks like suitable structural and conceptual conditions have been created in Albania, in order to perform the second demographic transition and change the family structure in a way that is similar to other Central and Eastern European countries. However, there are some characteristics that make of Albania a unique case among Europe's ex-communist countries. Structural changes in Albania before and after the 90's are extraordinary. The country attracted big investments that influenced the improvement of its infrastructure and the increasing of the number of the means of 
transport. But yet, the energetic and transport structure in Albania is far away from european standards (Broadband Commission for Digital Development, 2012; Encyclopedia of the Nations). There were some great intents to educate the population during the communist period. The Census of 2011 highlighted some positive indicators regarding the spread of educative activities among the population, and reported that $96 \%$ of the population over 10 years old go to school in Albania, while the percentage of the people over 10 years old that get higher education, increased from $5.5 \%$ in 2001 to about $11 \%$ in 2011 (Instituti I Statistikave, 2011). As for the urbanization and immigration, Albania is a special case of study. The infrastructure inherited from the communist regime was weak and the coming democracy brought a building boom and massive displacement of people from the deepest areas towards the big cities and from other cities to the capital, Tirana. The collapse of the communist regime caused also massive immigration to other countries and massive displacement inside the country (Chindea et al., 2008). This happened because along with the fall of the regime, people were no longer prohibited from moving in and out of the country. Consequently, immigration represents one of the most important social and economic phenomena in Albania during the last two decades (Chindea et al., 2008). The urban population in Albania in 2011 was about 54\%, overthrowing for the first time the ratio between urban and rural population (Instituti I Statistikave, 2011). The rise of urban areas, their residential population growth and the increasing of the population density brought new ways in organizing lifestyles, relationships and communication in general. Despite being one of the poorest countries in Europe, Albania has made some significant progress in income and consumption level growth. The country is now classified as a medium income country (Wold Bank, 2014). However, a big part of the country's economy is informal, being responsible for the $36 \%$ of the GDP during 1996-2012 (Boka et al., 2013). This is an important detail for the social protection policies in Albania, and also represents a major problem and a real challenge for these policies. The country's historical deficits, like the short experience in being an independent country and the lack of democracy, the law level of social and economic development, the deep political gaps and the authoritarian leaderships, can explain the difficult and long lasting transition and the problems that Albania faces today (Bertelsmann Stiftung, 2014). Naturally, the main reason behind these features of the albanian society must be looked for in the extremely tough communist regime that ruled the country for over 45 years, a regime that obstructed the rise and development of organizations and leaders, who would have had the right vision to lead the country towards democracy after the communism collapsed (Bertelsmann Stiftung, 2014). Now Albania is in a european integration phase, which means there's a series of standards to accomplish and political-economic challenges to be faced (Bertelsmann Stiftung, 2014).

The inclusion policy or the policy of social protection in Albania is a component of a greater general frame named National Strategy for Development and Integration (SKZHI) 2007-2013, which brings in a single document the perspectives of social and economic stable development, in the framework of the integration in the UE and realization of the Millennial Objectives (SKZHI, 2008). SKZHI outlines the vision of developing a "high life-standard country, integrated in the european and euroatlantic structures, democratic and warrant of the fundamental freedoms and human rights", aiming the wider involvement of the civil society, local communities, businesses and interest groups, academic, scientific and political structures of the country. One of the components of the SKZHI is social policy, which aims to increase the level of employment as a powerful tool of economic development, social cohesion and poverty reduction, through a flexible employment service, a social protection system that identifies people in need, an efficient pension system, the encouragement of women to participate in the labor market, a health care system that is flexible to demographic changes and an education system that ensures quality and inclusion of every child in it (SKZHI, 2008).

The benefit of the social assistance in Albania also known as "economic assistance" is a two phase process: First of all, the central power allocates the financial resources on a block for the municipalities and communes, based on the relevant level of poverty. The local units distribute the economic assistance for the families in need based on some requirements (SKZHI, 2008). The main problem is that the coverage and direct financial payment level is really low (less than $15 \%$ of poverty limit), which means the effect on poverty relief is weak and beneficiaries require additional financial resources (SKZHI, 2008).

Social assistance is one of the most applied forms of social protection in Albania. Actually, this form of social protection exists in almost every developed country. It serves to reduce the gaps created from the social protection scheme and to alleviate poverty. Social assistance aims to support only people in absolute need. They can be identified through evaluation and strict control of the income and other indicators, in order to let only the ones who need it the most benefit from it. In practice, the situation is completely different because no control can be absolute. This way, some people get these services unfairly, especially in countries with a high level of informal economy (like Albania, for instance). These are important 
mistakes, because they do cost in financial terms, and also make the public distrust the system of social protection (ILO, 2001).

On one hand, social assistance, so widespread in Albania, usually fails to help people who are in real need for these reasons: These people don't want to apply for social assistance because of the stigma related to it. They might not be aware of their right to benefit from social assistance. They might have difficulties in applying due to complicated procedures that require much time to be realized. Social assistance usually has a high degree of independence and administrative flexibility, making possible favoritism, clientelism and discrimination happen (ILO, 2001). On the other hand, the more severe the control and criteria for obtaining the social assistance, the more discouraged to apply people get, which brings the risk that the ones who really need these services never get to them.

In addition to this, daily residential services are offered to other unprotected groups like orphan children, disabled people, trafficking victims, people with social problems etc. In the framework of decentralizing the competencies and responsibilities, efforts are made to develop community level services in order to have greater chances to help people who live alone (SKZHI, 2008).

The Social Protection Strategy has these political and strategic priorities:

Social Assistance as the main tool for poverty reduction. It's important to rise efficiency in managing the direct financial payment programs through:

-Improving the information that identifies the most suitable families in need, be based on poverty maps, census and family surveys.

-Increasing the coverage of the needs of the beneficiary families, aiming to achieve the poverty level per person, but maintaining the roof of the minimal pension on national level. The monthly payment will be indexed in accordance with the family structure and differentiated according to its different member groups, by using the dotted evaluation formula of fulfilling the criteria, as well as according to the poverty level.

-Simplifying the procedures of the evaluation of the requesting families. Extending the conditionality of the economic assistance benefit through working all over the country, increasing transparency in funds distribution, decreasing the chances of abusive benefit and extending the income for families that engage in community works.

-Improving the energy subsidies (SKZHI, 2008).

Social Care, in order to offer services to the people in need, their families and their communities, through:

-Decentralizing social services. The local government will be responsible for planning and offering the services, while the rules for obtaining the services will be defined by the line Ministry. Residential service centers will pass on local governance administration on purpose, and new social services according to community needs will rise.

-Increasing cooperation with non-governmental organizations, as social services providers, and institutionalizing this cooperation through license.

- Transforming gradually the residential services into movable community services, offering alternatives for accommodation, training, education and rehabilitation of people in need.

-Guaranteeing the quality of services according to the standards in power (SKZHI, 2008). 
Social inclusion, in order to enable the equal participation in development of vulnerable groups like children, Roma and disabled people (PAK). Sustainable development will give to the children better opportunities to begin life.

The strategic priority of the Intersectoral Strategy of Social Inclusion is to increase the chances people have to generate income, facilitate the access to the services and help groups in need (SKZHI, 2008). There are several strategic documents about helping groups in need, such as:

Children:

The national strategy for the children covers every aspect of their life, giving priority to the activities that alleviate poverty.

The measures include: in the field of justice: special treatment of Children's penal issues and improvement of the procedures and prison conditions for minors, wider use of social workers, establishment of the Juvenile Reeducation Institute; in the field of healthcare: integrated management of the patient; in the field of education: establishment of local professional units in order to deal with the obstacles of children's integration and development, implementation of the compulsory education to prevent child labor, massive establishment of local units to ensure the respect and protection of children's rights (SKZHI, 2008).

\section{Roma People:}

The aim is to achieve the collaboration and implementation of policies that alleviate poverty for this minority group, reduce discrimination and improve the integration through: registering them in order to make it possible to benefit from the services; stimulating school attendance through supporting children that learn Albanian, providing teacher that speak Romani and suitable educative programs for adults; saving their culture and tradition and empowering roma girls and women; improving their access to social services and economic assistance; covering the expenses for health-care and stimulating family planning, pre-birth and post-partum care; support for the accommodation and infrastructure of romani communities; access to public order structures through their recruitment.

Disabled people:

The aim is to integrate policies and measures that encourage the participation of disabled people in each aspect of life through: facilitating the usage of public buildings and infrastructure; early discovering and preventing of disabilities and accordance of health-care, social services and educational programs; facilitating the employment of disabled people, protecting them at work and involving them in professional training; reinforcing the state's capacity and improving the legal framework towards disability policies (SKZHI, 2008).

Social Insurance:

The social insurances system like we know it today, came to power in 1993, based on the principle of social justice. Social insurances are part of the social justice system which protects individuals in case their income decrease, so that they can have a certain living standard, improve it and have access to basic social and health services. SKZHI aims to restructure the public pensions system and to encourage the development of a social security financial market; transform the singular column system of pensions to a multiple column one and create a third column of the pensions; create a suitable climate for the operation of private companies in the field of social services; increase the public trust in private schemes of pensions and encourage them to take part in these schemes, improve the control and regulation of these companies and regularly monitor their financial situation, so that public investments can be safe; create a better connection between contributions and pensions and balance the scheme of pensions based on contributions: improve the administration scheme of pensions in general etc (SKZHI, 2008). The Institute of Social Insurances was established in 1992 (ISS) to manage the scheme. Actually it's a non-profit scheme that protects employed people in case of disease, unemployment, maternity, accident at work/professional illness, older age, disability or loss of the family keeper or other economically active people (selfemployed and employers), based on the principle "pay-as-you-go", on the individual responsibility over social risks and the solidarity among generations (Selita, 2014). The scheme is funded by the mandatory contributions of the employers, employees and self-employed, as long as they are employed. The payment of benefits represent amounts of money that 
should cover at least the minimal living standard. However, economic and social changes brought new elements in the scheme including the voluntary and supplementary insurance, the creation of private pensions institutions (Selita, 2014), practices that have been applied in other countries. Voluntary insurance permits unemployed people to enter the scheme; supplementary insurance creates the opportunity for certain people (high officials, military and private subjects) to obtain earlier or greater pensions.

Health-care and social insurance:

Another development towards alleviating the effects of the financial transition of the political system and supporting groups in need was the creation on the Institute of Health Care Insurance (ISKSH) in 1994 (ISKSH, 2014). Everyone has the right to health insurance according to the procedure designed by the law (Kushtetuta e Republikes se Shqiperise). This article marks the beginning of the solidarity towards people in need in the albanian society, securing this way the support of the society for this groups in relation to protection and health promotion aspects. Health insurance is part of the social protection system. It protects individuals in cases of diseases or helps their rehabilitation after the illness appears or prevents it. There are several measures taken in this context, such as defining the criteria to participate in the health insurances scheme, offering for free the most necessary services of public health, refunding the cost of medications, balancing the distribution of health services by geographical areas and population number, creating a single buyer of the health public services, in order to improve the system funding and increase its level of security, improving the administration system etc (SKZHI, 2008). However, one of the main characteristics of the transition in Albania is the fact that despite the existence of a relatively complete and modern legislation, its implementation remains a problem.

\section{Results}

Social protection elements are found in other components of the SKZHI, like the component of gender equality and domestic violence prevention, in the components regarding sports, youth and employment, which are summarized under the term "Social Policies" in the strategic document of SKZHI. All these components aim to increase the well-being and social inclusion of certain social groups, which testifies the solidarity of the society (SKZHI, 2008). It's clear that the second demographic transition is happening in Albania, and it's changing the structure of the albanian family. Naturally, these changes in the family structure must be accompanied by relevant changes and adjustments in social protection and inclusion policies, in order to create better answers for the new reality.

Actually, the evaluating reports of the social protection policies in Albania highlight some problematic aspects. For example, most of the unemployed people in Albania don't qualify or don't have the right to benefit from the unemployment insurance because it's given only to those who have paid the social contributions during their last year of employment (European Commission, 2008). Only 5\% of the registered unemployed people in Albania are qualified to obtain the unemployment insurance, based on the actual rules. Analyzes of different reports suggests that cooperation and integration between institutions that deal with the social protection policies and provide these services in the community should be improved significantly (European Commission, 2008). Lack of coordination and awareness related to responsibilities separation between institutions can become an obstacle for people to obtain what belongs to them, can complicate unnecessarily the procedures of economic assistance and give inadequate information regarding social protection schemes to the interested parts.

Albania still remains a country in transition, with a fragile economy and a high level of informal economy. However, efforts are taken to improve the situation and come closer to european standards, which is particularly important since Albania officially won the status of candidate for accession to European Union on 24 June 2014 (European Commission, 2014). In this context, efforts are made to approximate social protection policies with european policies. This way, SKZHI is a strategic document where the Social Inclusion and Social Protection Strategies are integral components focused on poverty and social exclusion risks (European Commission, 2008).

\section{Conclusions}

The public system of social protection covers a limited category of people in need that includes old people, disabled people and orphan children, based on the contributions given by the employees and employers. This system works better under 
the conditions of an economy with a high level of formality, which is not the case of Albania (European Commission, 2008). Changes in family structure in the context of the second demographic transition have questioned the ability of the social protection system in Albania to achieve the minimal standards of social support (European Commission, 2008 ).

The gap between central and local government (in terms of funds and lack of the infrastructure to offer protection services and social support locally) and the disorientation of local structures regarding their responsibilities and/or dependency issues of relevant structures and/or their motivation should be resolved as quick as possible in order to improve the quality and the coverage level of protection services and social support.

There is no doubt that social policies, if implemented in the right way, help reducing poverty and encourage the participation of individuals in need in the labor market. Changes in the family structure in Albania strongly suggests changing the policies of welfare, social protection and inclusion, in order to answer the different needs of the Albanian families and be suitable for the new reality created.

\section{References:}

[1] Bertelsmann Stiftung, BTI (2014). Albania Country Report. Gutersloh: Bertelsmann Stiftung, (2014). [Online] Available: http://www.bti-project.org/fileadmin/Inhalte/reports/2014/pdf/BTI\%202014\%20Albania.pdf (July 30, 2014)

[2] Boka, M., \& Torluccio, G. Informal economy in Albania. Academic Journal of Interdisciplinary Studies, (2013); $\mathrm{d}(8): 212-221$.

[3] Broadband Commission for Digital Development. Strategies for the promotion of broadband services and infrastructure: A case study on Albania. (September, 2012). [Online] Available: http://www.itu.int/ITUD/treg/publications/BBD_MDG_Albania_Final.pdf (August, 2014)

[4] Chindea, A., Majkowska-Tomkin. M., Mattila. H., \& Pastor Siar, S. (Ed.) Migration in Albania: a country profile (2008). International Organization for Migration. [Online] Available:

http://www.marrirc.org/upload/Documents/Albania-2008.pdf (August, 2014)

[5] Encyclopedia of the Nations. Albania - Infrastructure, power, and communications. [Online] Available: http://www.nationsencyclopedia.com/economies/Europe/Albania Infrastructure- Power-andCommunications.html (August, 2014)

[6] European Commission. EU candidate status for Albania. Press Release. Memo/14/439. Brussels (June 24, 2014). [Online] Available: europa.eu/rapid/press-release_MEMO-4-439_en.pdf (August, 2014)

[7] European Commission. Social inclusion and social protection in Albania. European Commission. DirectorateGeneral for Employment, Social Affairs and Equal Opportunities. (September, 2008)

[8] Historiku i Sigurimeve te Kujdesit Shendetesor ne Shqiperi. Fondi i Sigurimit te Detyrueshem te Kujdesit Shendetesor. [Online] Available:

http://www.isksh.com.al/index.php?option=com_content\&amp;view=article\&amp;id=65\&amp;ltemid=94 (August, 2014)

[9] Instituti i Statistikave. Censusi i popullsise dhe banesave (2011). [Online]Available: http://www.instat.gov.al/media/177354/main_results_population_and_housing_census_2011.pdf (August, 2014)

[10] International Labour Organization. Social security: issues, challenges and prospects. Sixth item on the agenda. (2001). International Labour Office. Geneva.

[11] Kushtetuta e Republikes se Shqiperise. [Online] Available: http://www.mpcs.gov.al/dpshb/images/stories/files/Kushtetuta E Republikes se Shqiperise.pdf, (August, 2014) 
[12] Pfaller, A. System Transformation and Social Protection. (2001). Friedrich Ebert Stiftung. Digitale Bibliothek. [Online] Available: http://library.fes.de/fulltext/id/01172.htm\#E9E1 (August, 2014)

[13] Reframing Social Policy: actors, dimensions and reforms. Friedrich Ebert Stiftung Office Skopje. University \&quot;Ss Cyril and Methodius\&quot; - Skopje Faculty of Philosophy, Institute of Social Work and Social Policy. Skopje. [Online] Available: http://www.fes.org.mk/pdf/Social\%20Policy\%20ENGLISH.pdf (August, 2014)

[14] Republika e Shqiperise. Keshilli i Ministrave. Strategjia Kombetare per Zhvillim dhe Integrim 2007-2013 (SKZHI). (March, 2008). [Online] Available: http://www.pad.gov.al/images/Arkiva/SKZHI 2007-2013.pdf (August, 2014)

[15] Selita, M. Nje veshtrim mbi historikun e Sigurimeve Shoqerore ne Shqiperi. Instituti i Sigurimeve Shoqerore. [Online] Available: http://www.issh.gov.al/al/nje-veshtrim-mbi-historikun- e-sigurimeve-shoqerore-ne-shqiperi/ (August, 2014)

[16] World Bank. Albania overview. [Online] Available: http://www.worldbank.org/en/country/albania/overview\#1 (August, 2014) 